\title{
MANUFACTURING SOLUTIONS FOR SMALL AND MICRO COMPONENTS
}

\author{
CRUZ, F.
}

Abstract: Micro Manufacturing is the production of small components and products, which have not been possible until the recent introduction of ground breaking technologies and techniques in the traditional manufacturing processes.

This comprises the manufacture of parts in the micrometer and manometer ranges. This exciting emerging niche, allowing miniaturisation of components particularly in the consumer electronics, medical, pharmaceutical, automotive, aerospace, jewellery, micro optics and defence markets, is now available in all the major traditional groups of manufacturing processes (Macro Manufacturing), providing the production of micro-scale parts. Micro-and Nano Manufacturing Technologies (MNT) make use of a variety of materials, components and knowledge-based technologies providing functionality and intelligence to highly miniaturised systems. This paper presents an updated overview of these emerging manufacturing technologies.

Key words: micro manufacturing, nano manufacturing, miniaturisation, micro machining, micro tooling
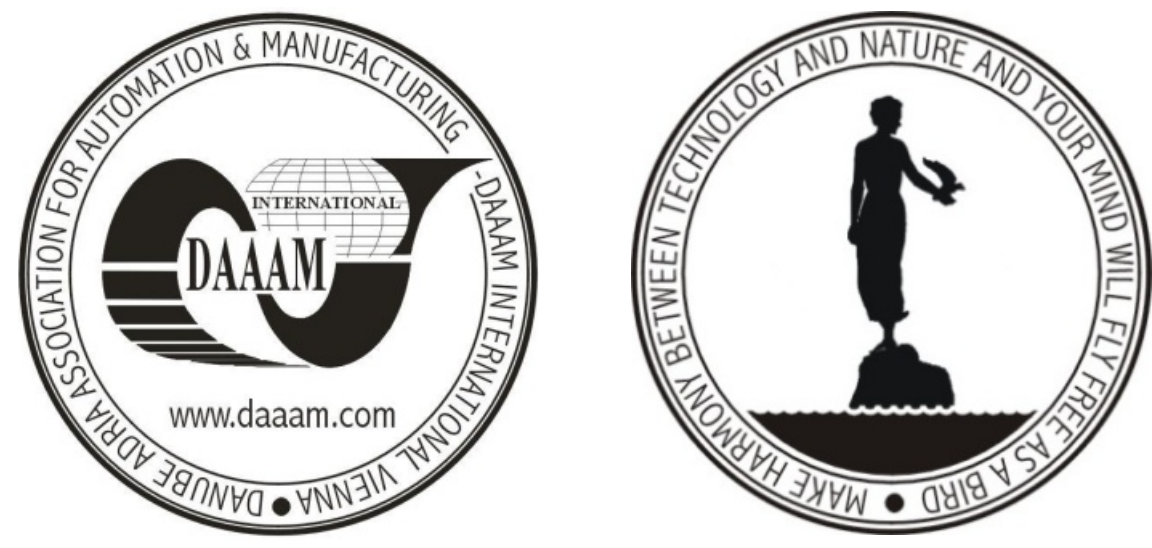

Author data: Assistant Prof., PhD (Eng.), MSc (Eng.) Cruz, F[ernando]; Polytechnic Institute of Setubal, Campus do IPS, Estefanilha, 2910-761 Setubal, Portugal; fcruz@est.ips.pt

This Publication has to be referred as: Cruz, F[ernando] (2009). Manufacturing Solutions for Small and Micro Components, Chapter 33 in DAAAM International Scientific Book 2009, pp. 315-322, B. Katalinic (Ed.), Published by DAAAM International, ISBN 978-3-901509-69-8, ISSN 1726-9687, Vienna, Austria DOI: $10.2507 /$ daaam.scibook.2009.33 